[41] The Impact of Technology on Journalism (2006). Matthew Sparks. Available at: https://matthewsparkes.wordpress. com/2006/02/17/the-impact-of-technology-on-journalism/ Last accessed: 20.03.2021

[42] Dhaka Tribune (2020). Available at: https://www.dhakatribune.com/bangladesh/government-affairs/2020/07/31/govt-releaseslist-of-44-verified-online-news-portals Last accessed: 20.03.2021

How to cite. Khan, A. K., Shnaider, A. (2021). The development trends and features of online news websites in Bangladesh. EUREKA: Social and Humanities, 3, 41-58. doi: http://doi.org/10.21303/2504-5571.2021.001858

\title{
ANALYSIS OF CHANGES IN THE ADMINISTRATIVE- TERRITORIAL STATUS OF MONOPROFILE CITIES OF DONBAS (LATE 1940s - 1980s)
}

\author{
Valeriy Bohunenko \\ Department of Domestic and Foreign History \\ Horlivka Institute for Foreign Languages of the State Higher Educational Institution "Donbas \\ State Pedagogical University" \\ 24 Vasylia Pershyna str., Bakhmut, Donetsk region, Ukraine, 84511 \\ bogunenkovalery@gmail.com
}

\begin{abstract}
Absract
Transformations of the administrative-territorial status of monoprofile cities of Donbas in the context of development of structural-settlement structure of the region in the late 1940s and 1980s are considered. The urgency of the study is due to the reform of decentralization in Ukraine - changes in the order of local self-government and territorial organization of power. Its goal is to create communities that are self-sufficient and effective in the economic, administrative and socio-cultural dimensions. In the course of reform, monoprofile cities often acquire the status of centers of united territorial communities. In assessing the relevance of such decisions to the purpose of the reform, it is advisable to examine the relationship of structural-settlement, socio-economic and administrative-territorial status of these cities in historical retrospect. It turns out that the monoprofile cities of the region are an industrial-urban phenomenon, the genesis of which influenced the formation of the specifics of the settlement structure of Donbas. During the study period, the number of such cities more than doubled, reaching more than sixty cities in the late 1980s. Their share among the settlements of the region with the administrative status of a city was at that time two thirds. The emergence of monoprofile cities in the region in large numbers in the 1940s - 1980s is associated with government-industrial policy. At the same time, the structural and settlement importance of these settlements was reflected in their acquisition of the administrative-territorial status of region or district cities. From the beginning of the study period, the vast majority of cities with a narrow industrial base in the region belonged to the cities of district subordination, as they did not meet high enough urban criteria. In the urbanized region, in the presence of other, more powerful urban centers, the corresponding role in the administrative-territorial organization programmed the secondary nature of their structural settlement development. In particular, it did not contribute to the formation of micro-regions around these cities, which must be taken into account in the current conditions of reforming local self-government and territorial organization in the country.
\end{abstract}

Keywords: monoprofile cities, Donbas, administrative-territorial status, settlement structure.

DOI: $10.21303 / 2504-5571.2021 .001862$

\section{Introduction}

The development of the settlement structure of urbanized regions is associated with the problem of spreading the «urban environment», its compliance with the administrative boundaries of urban settlements and their administrative status [1, p. 64-65]. Important is 
the question of the mutual influence of economic, social processes and forms of administrative-territorial organization.

In recent years, the urgency of studying the structural and settlement features of Donbas (in the version of its definition as the territory of Donetsk and Luhansk regions), in connection with the decentralization reform - changing the order of local government and territorial organization, as well as developing a regional development strategy [2] increased. Donbas is the most urbanized region of Ukraine: as of January 1, 2020, about $90 \%$ of its inhabitants were urban population [3]. Seventy of the eighty-nine cities of Donbas [4] belong to the category of cities with a narrow economic base. In the scientific literature they are referred to as «monofunctional» [5], «monoprofile» [6], «monocities» [7, 8]. Sixty-eight of these settlements received the urban status during the existence of the USSR [9]. Many similar cities today in the process of decentralization reform are given the status of administrative centers of the newly formed united territorial communities [10, p. 39]. The development of social infrastructure of the centers is expected due to the growth of economic capacity of communities, including due to the development of city-forming production [11, p. 54-55].

Dozens of monoprofile cities, which now make up about half of the urban fund of Donbas, appeared in the decades immediately preceding the era of Ukraine's independence [9]. This means that at that time the economic-industrial, architectural-planning processes in the region determined the transformations of its settlement structure, influenced the prospects for its further development. In this regard, the question arises about the nature of the formation of these cities in the system of settlement interaction in the Donbas, in particular - in its administrative-territorial aspect.

The aim of the work is to highlight the nature of the administrative formation of monoprofile cities of Donbas in the late 1950s - 1980s in the context of transformations of the settlement structure of the region.

\section{Materials and methods}

The monoprofile cities of Donbas as an object of study have especially attracted the attention of researchers in the last decade. Economic, historical and cultural issues of these cities in the context of urban and regional studies were studied by K. Kuzina, V. Kulikov, I. Sklokina [12] and others. Among the researchers of the history of Donbas, in whose works this topic is significantly covered, we should mention V. Smoliy, S. Kulchytsky, L. Yakubova [13]. In the researches of these authors the exclusive role of the accelerated development of the industry in fundamental shifts of the settlement structure of the region is proved, including through the emergence of a large number of monoprofile cities. The history of administrative-territorial changes in the USSR was studied by J. Vermenych, O. Androschuk [14, 15] and others. At that administrative and organizational features of formation of monocities of Donbass, their value in the structural-settlement interaction didn't become a subject of separate consideration.

The paper uses sources of an official nature of the existence of the USSR, which contain information on the implementation of the state administrative-territorial policy in the region. Among them - decrees, resolutions, orders of the authorities, included in the collection «History of the administrative-territorial division of the Donetsk region in 1919-2000» [16]. An important place is occupied by archival materials - projects of zoning of Donbas and development of cities of the republic, performed by research institutions [17, 18], and the development of the classification of cities of the USSR [19]. Statistical materials [3, 20] reference books on the administrative-territorial structure of the USSR in the 1940s, 1970s [21, 22], etc. were also used.

The study uses the following methods: historical retrospective, problem-chronological, historical-genetic, historical-typological, statistical.

\section{Results}

In the Donbas at the beginning of the study period there was an extensive system of urban settlements - 49 cities and 173 urban-type settlements [21, p. 79, 467]. It arose as a result of rapid urbanization, associated with the forced industrialization processes of the 1920s and 1930s. At that the then provisions on bringing production closer to raw material sources and methods of building socialist cities with a mandatory «proletarian core» stipulated the emergence of more than three 
dozen monoprofile cities in the region, which accounted for about two-thirds of the region's urban fund. At the same time in the USSR there was a hierarchy of cities - republican, regional and district subordination, which took shape after the establishment in the early 1930's rules of administrative division of the republic into regions, composed of districts [16, p. 77]. Acquisition of the status depended primarily on the population; cities became district ones, the number of inhabitants of which did not exceed 50 thousand people [14, p. 134]. The administrative importance of monoprofile cities in the region was different (Table 1).

Table 1

Administrative importance of the cities of Donbas in the late 1940s [19, sheet. 11; 21, p. 79, 467].

\begin{tabular}{|c|c|c|c|}
\hline \multicolumn{2}{|c|}{$\begin{array}{c}\text { Number of cities of regional importance / monoprofile of } \\
\text { which }\end{array}$} & \multicolumn{2}{|c|}{$\begin{array}{l}\text { Number of cities of district importance / monoprofile } 0 \\
\text { which }\end{array}$} \\
\hline Stalin region & Voroshilovgrad region & Stalin region & Voroshilovgrad region \\
\hline $12 / 2$ & $5 / 1$ & $16 / 14$ & $16 / 13$ \\
\hline \multicolumn{2}{|c|}{ Together in two regions: $17 / 3$} & \multicolumn{2}{|c|}{ Together in two regions: $32 / 27$} \\
\hline
\end{tabular}

The total number of cities in the region was 49 , of which monoprofile was 30 . At the same time, both in the republic as a whole and in Donbas, «district» cities accounted for about two-thirds of cities; at the same time in the region among the latter the absolute majority were monoprofile cities. Their number continued to grow: at the end of the post-war reconstruction phase, in 1953, two mining villages in the Donbass received the status of a city - Dobropillya and Shakhtarsk.

At the same time, the structural and settlement importance of the mono-cities of the region was not dominant: there was their «attraction» to large multifunctional cities with a developed socio-cultural infrastructure. This was especially the case in ten «urban nodes» (where agglomerations were formed) - Stalin-Makeyevsky, Lysychansky-Rubezhansky, Voroshilovgradsky, Chistyakov-Snizhnyansky, Kadyevsk-Alchevsky, Horlivsky, Krasnodon-Sorokinsky, Bokov-Khrustalsky, Krasnoarmeysky and Prytoretsky [17, sheet. 30, 82-83].

It should be noted, that the phenomenon of «satellite cities» in Donbas could be formed regardless of administrative status. Thus, Avdiivka, entering the Yasynuvata City Council, was in fact a «satellite city» of Stalino, primarily due to the dominance of the latter in the industrial and socio-cultural spheres. Instead, Chasiv-Yar, as a «satellite city» of Artemivsk, belonged to its City Council [21, p. 472, 476].

Changes in the administrative and territorial organization in the region took place in the second half of the 1950s and mid-1960s. This time is politically connected with «Khrushchev's thaw», and economically - with attempts to carry out repeated «catching up» modernization in the «Soviet country». In the context of socio-economic tasks of this time, the criteria for streamlining the status of settlements were updated. Thus, on December 30, 1956, the Presidium of the Verkhovna Rada of the USSR issued a Decree «On the Procedure for Assigning Settlements to the Category of Cities, Urban-Type Settlements, and Worker Settlements of the Ukrainian SSR.» According to this document, in order to obtain the status of a city, the settlement needed to have not only a strong industrial base and communal services, but also a developed state housing stock, social and cultural infrastructure. The number of inhabitants had to be at least 10,000, employed mainly in industrial production (taking into account both workers and employees and members of their families). The number of inhabitants of urban-type settlements had to be at least 2 thousand people, worker settlements - at least 500 people [14, p. 136].

In the late 1950s, the urbanization of the region intensified. Most urban settlements at that time were urban-type ones (there were 314 of them), 62 settlements had the status of cities - 13 more than in the late 1940s. It is significant, that all of the new cities were monoprofile. The growing structural and settlement weight of such cities in Donbas at this time is largely due to «Komsomol buildings». The urban population in the region at that time was about 5,500 thousand people, more than $80 \%$ of the population of the region [20, p. 26]. By the mid-1960s, the total number of settlements with admin- 
istrative status in the region had grown by more than two dozen. At the same time, city formation took place both through the establishment of settlements around new industrial facilities (primarily mines; as an example, Novodruzhesk, Yunokomunarivsk, etc.) and by allocating the former districts of Stakhanov - Bryanka and Kirovsk as separate cities [23, p. 277]. There was also a union of cities - monoprofile Proletarsk, as well as Verkhniy and Lysychansk [23, p. 452].

It should be noted the impact since then on the administrative and organizational processes in the region, declared by the party and government leadership «blurring the boundaries between urban and rural areas.» This provided for the creation of «agro-cities» with a high level of utilities, infrastructure and more. The implementation of this policy can be considered the granting of the status of a city of Alexandrovsk, Luhansk region - settlement with a limited industrial and demographic base [23, p. 124]. It is also worth mentioning the impact of structural and administrative experiments of the USSR government on the administrative status of cities in the region. Thus, due to the creation of «regional industrial councils» by the Decree of the Presidium of the Verkhovna Rada of the USSR of December 30, 1962, it included more than fifty important industrial settlements in the category of cities of regional importance. Among them were the cities of the Donetsk region: Dzerzhinsk, Krasnoarmeysk, Snizhne and Khartsyzsk, as well as Luhansk region - Sverdlovsk and Severodonetsk [16, p. 170-171]. Four of these six cities were monoprofile; regional importance was lost by them after the abolition of this division.

At the stage of partial economic reforms in the mid-1960s and early 1970s, administrative and territorial transformations in the region continued to be determined primarily by the government economic policy. The weight of profile governmental, research and specialized design institutions has increased in the planning of relevant changes. Thus, in the late 1960s, the government of the USSR developed issues of urban conditions and prospects for the development of the city network of the republic for the ninth or tenth part of the five-year plan. Numerous institutions were involved in this process at the level of meetings, hearings, preparation of conclusions, etc. Among them were: the State Committee for Construction of the USSR (primarily the district planning department), the State Planning Committee of the USSR, the State Institute of Urban Planning, the Urban Development Group of the Council for the Study of Productive Forces of the Academy of Sciences of the USSR [24]. It is important to note, that at this stage there was an attempt by the government to «unload large cities» in industrial terms [18].

However, qualitative changes in industrial and urban policy, in particular - in the transformation of monoprofile cities into multiprofile ones - have not happened at this time. The total number of cities in the USSR at the beginning of 1972 was 390, of which 2 were of national importance, 111 - of regional importance; there were 884 urban-type settlements. At that time, urban settlements of Donbas accounted for $26 \%$ of the republic's urban fund; cities of the region accounted for $21 \%$ of the cities of the USSR [22, p. 5]. At the same time, the share of monoprofile settlements in the region among cities of regional and district importance has changed somewhat (Table 2).

Table 2

Administrative status of Donbas cities in the early 1970s [22, p. 53-55, p. 97-100]

\begin{tabular}{|c|c|c|c|}
\hline \multicolumn{2}{|c|}{$\begin{array}{c}\text { Number of cities of regional importance / of which are } \\
\text { monoprofile }\end{array}$} & \multicolumn{2}{|c|}{$\begin{array}{c}\text { Number of cities of district importance / of which are } \\
\text { monoprofile }\end{array}$} \\
\hline Donetsk region & Voroshilovgrad region & Donetsk region & Voroshilovgrad region \\
\hline $19 / 7$ & $14 / 10$ & $30 / 30$ & $20 / 17$ \\
\hline \multicolumn{2}{|c|}{ Together in two regions: $33 / 17$} & \multicolumn{2}{|c|}{ Together in two regions: $50 / 47$} \\
\hline
\end{tabular}

Thus, in the Donetsk region at that time there were 49 cities and 141 urban-type settlements. Among 19 cities of regional subordination, monoprofile ones were about 2/5, while among 30 cities of district subordination, all were monoprofile ones [22, p. 97-100]. In the Voroshilovgrad region at that time there were 34 cities and 104 urban-type settlements. The total number of cities in the 
region was $83 ; 64$ of them were monoprofile - more than $77 \%$ of cities. Taking into account urban-type settlements, the share of monoprofile cities of Donbas was $19.5 \%$ of the total number of urban settlements. Their administrative weight in the region at this time was significant, as among 14 cities of regional subordination, monoprofile ones accounted for $2 / 3$. At the same time, among the cities of district subordination, settlements of this category were the absolute majority - more than $4 / 5$ cities [22, p. 53-55]. It can be argued that, despite the government's attention to industrial and urbanization processes, attempts to increase their scientific and methodological level, the structural and settlement development of Donbas at this stage took place under an inertial scenario. At that time, only monoprofile cities received the status of a city, due to which their relative number grew among cities of regional importance, and especially among district ones. It is noteworthy, that at that time four times fewer settlements than at the previous stage received the city status in the region - only five: in 1966 - monoprofile Bilytske, Belozerske, Zhdanovka, Novoazovsk; in 1972 - Sukhodolsk [9].

In the following years, at the stage of curtailment of reforms and escalation of crisis phenomena in the mid-1970s - mid-1980s, the settlement structure hardly changed (Table 3), due to the decrease in the intensity of urbonogenesis.

Table 3

Administrative status of Donbas cities in the late 1970s [25, p. 37-39, p. 68-71]

\begin{tabular}{|c|c|c|c|}
\hline \multicolumn{2}{|c|}{$\begin{array}{c}\text { Number of cities of regional importance / of which are } \\
\text { monoprofile }\end{array}$} & \multicolumn{2}{|c|}{$\begin{array}{c}\text { Number of cities of district importance / of which are } \\
\text { monoprofile }\end{array}$} \\
\hline Donetsk region & Voroshilovgrad region & Donetsk region & Voroshilovgrad region \\
\hline $20 / 8$ & $14 / 10$ & $29 / 29$ & $23 / 21$ \\
\hline \multicolumn{2}{|c|}{ Together in two regions: $34 / 18$} & \multicolumn{2}{|c|}{ Together in two regions: $52 / 50$} \\
\hline
\end{tabular}

On January 1, 1979 in the Donetsk region, there were 49 cities and 134 "urban-type settlements". Among the cities of regional subordination in the Donetsk region, monoprofile ones accounted for almost half; at the same time, all cities of district importance were monoprofile. At the same time, 18 of them were "satellite cities" - subordinated to the city councils of other cities [25, p. 68-71]. In the Voroshilovgrad region at that time, there were 37 cities and 105 urban-type settlements. Thus from the cities of regional subordination monoprofile again made about 2/3; among the cities of district subordination, almost all (except "atypical" Kreminna and Starobilsk) are monoprofile. At that time, 12 cities were subordinated to the City Councils of other cities in the region, one (Oleksandrivka) was part of the Artemivsk district of Voroshilovgrad [25, p. 37-39].

At the last stage of the period under study - a time of the acute socio-economic crisis and attempts to radically reform the Soviet economic system in the second half of the 1980s - structural and settlement transformations in the region virtually stopped. Thus, in 1987 the situation here was almost the same as in the previous decade, except for the appearance of another «urban-type settlement» in the Donetsk region [26, p. 64]. For two years in the Donetsk region, the settlement of Vugledar became a city of district subordination [9]. In total, at the end of the 1980s, there were sixty-eight monoprofile cities in the region, with a total of eighty-seven cities; the vast majority of which were cities of district importance.

\section{Results and discussion}

According to the study, in the period from the late 1940s to the late 1980s there were intensive urbanization processes in the Donbas, the number of cities has almost doubled. At the same time, despite significant absolute quantitative changes, the share of monoprofile cities in the Donbas at this time was constantly more than $2 / 3$ of the settlements with the status of a city. The sharp increase in the number of such settlements in this area was due to the government's industrial policy. 
Industrial and urban processes in the region at this time led to the consolidation of the administrative specifics of monoprofile cities. This primarily concerned the belonging to the category of regional or district cities, the criterion for which was mainly the population number. Already at the beginning of the study period, the vast majority of the thirty cities with a narrow industrial base in the region (9/10) belonged to the cities of district subordination. In four decades, the number of monoprofile cities has more than doubled, reaching 64 settlements in the late 1980s. At the same time, about $4 / 5$ of the settlements of this category belonged to the cities of district subordination. More than 2/5 of the monoprofile cities in the region at the end of the study period belonged to the so-called «satellite cities», included in the city councils of other cities. This circumstance should have especially complicated their socio-cultural development, programming the «attraction» of the population to cities of regional importance as more powerful centers of urban life.

\section{Conclusions}

1. The development of the administrative-territorial organization of Donbas in the late 1940s and 1980s is largely connected with the phenomenon of monoprofile cities. At the same time, changes in the status of these cities have led to the absolute dominance of cities of district subordination among them in the region.

2. The specificity of this administrative-territorial status in the urbanized region influenced the fact that the monoprofile cities were assigned secondary importance in the structural settlement interaction.

3. Due to the effect of the administrative factor in Donbas, the formation of microregions around mono-profile cities was complicated. This was especially true for the so-called «satellite cities», subordinated to the city councils of other ones.

These historical circumstances must be taken into account today in the context of decentralization reform in Ukraine, during the formation of united territorial communities around monoprofile cities in the region.

\section{References}

[1] Strizoe, A. (2017). Deurbanization of Modern Society: Nature, Specifics, Risks. Vestnik Volgogradskogo Gosudarstvennogo Universiteta. Serija 7. Filosofiya. Sociologiya i Socialnye Tehnologii, 16 (1), 64-73. doi: http://doi.org/10.15688/jvolsu7.2017.1.7

[2] Pro zatverdzhennia Derzhavnoi stratehii rehionalnoho rozvytku na 2021-2027 roky (2020). Postanova Kabinetu Ministriv Ukrainy No. 695. 20.05.2020. Available at: https:/www.kmu.gov.ua/npas/pro-zatverdzhennya-derzhavnoyi-strategiyi-regionalnogo-rozvitku-na-20212027-t50820 Last accessed: 19.04.2021

[3] Number of existing population of Ukraine as of January 1, 2020 (2020). State Statistics Service of Ukraine. Kyiv. Available at: http:/www.ukrstat.gov.ua/druk/publicat/kat_u/2020/zb/05/zb_chuselnist\%202019.pdf Last accessed: 20.04.2021

[4] Administratyvno-terytorialnyi ustrii Ukrainy za stanom na 01.03.2021. Available at: http://static.rada.gov.ua/zakon/new/ NEWSAIT/ADM/zmist.html Last accessed: 19.04.2021

[5] Kuzmenko, L. M., Soldak, M. O. (2010). Monofunctional Sities: Problems, Support Provision and Development. Ekonomichnyi visnyk Donbasu, 4, 8388.

[6] Moiseeva, E., Mayburov, I. (2011). Sotsialno-ekonomicheskie problemy monoprofilnykh gorodov i byudzhetno-nalogovye instrumenty razvitiya i stimulirovaniya ikh razvitiya. Svit finansiv, 1, 8690.

[7] Borges, M. J., Torres, S. B. (2012). Company Towns: Concepts, Historiography, and Approaches. Company Towns. New York, 1-40. doi: http://doi.org/10.1057/9781137024671_1

[8] Aron, L. (2009). Darkness on the Edge of Monotown. The New York Times. Available at: https://www.nytimes.com/2009/10/17/ opinion/17aron.html Last accessed: 19.04.2021

[9] Promislovi monomista Donechchini ta Luganschini. Available at: http:/www.historians.in.ua/images/sampledata/hist-images/rizne/2018/03/monomista-table.pdf Last accessed: 14.04.2021

[10] Kravtsiv, V. S. (Ed.) (2016). Administratyvno-terytorialnyi ustrii Ukrainy: metodolohichni osnovy ta praktyka reformuvannia. Lviv: DU «Instytut rehionalnykh doslidzhen imeni M. I. Dolishnoho NAN Ukrainy, 264.

[11] Lytvyn, V. (2015) Administratyvno terytorialnyi ustrii Ukrainy: retrospektyvne bachennia ta perspektyvy reformuvannia. Available at: http://www.golos.com.ua/article/255545 Last accessed: 20.04.2021

[12] Kulikov, V., Sklokina, I. (Ed.) (2018). Pratsia, vysnazhennia ta uspikh: promyslovi monomista Donbasu. Lviv: FOP Shumylovych, 244. 
[13] Smolii, V., Kulchytskyi, S., Yakubova, L. (2016). Donbas i Krym v ekonomichnomu, suspilno-politychnomu ta etnokulturnomu prostori Ukrainy: istorychnyi dosvid, moderni vyklyky, perspektyvy. Kyiv: Instytut istorii Ukrainy NAN Ukrainy, 616.

[14] Androshchuk, O. V. (2006). Miski poselennia v systemi terytorialnoho ustroiu URSR 40-60-kh rr. XX st. Kraieznavstvo, $1-4,134-140$.

[15] Vermenych, Ya. V., Androshchuk, O. V. (2014). Zminy administratyvno-terytorialnoho ustroiu Ukrainy XX-XXI st. Kyiv: Instytut istorii Ukrainy NAN Ukrainy, 182.

[16] Istoriya administrativno-territorialnogo deleniya Donetskoy oblasti v 1919-2000 gg. (2001). Donetsk, 212.

[17] Raionnoe planyrovanye Donetskoho basseina. TsDAVO Ukrainy (Tsentr. derzh. arkhiv vyshch. orhaniv vlady ta upr. Ukrainy). F. 4906. Op. 2. Spr. 263. 281 ark.

[18] Materialy (dovidky, rozrakhunky) z rozghruzky mist Dnipropetrovska, Zaporizhzhia ta Kharkova vid promyslovykh pidpryiemstv, orhanizatsii, zakladiv ta navchalnykh zakladiv, perebuvannia kotrykh $v$ tsykh mistakh ye nedotsilnym abo ekonomichno neobgruntovanym. TsDAVO Ukrainy (Tsentr. derzh. arkhiv vyshch. orhaniv vlady ta upr. Ukrainy). F. 337. Op. 2. Spr. 304. 166 ark.

[19] Klassyfykatsyia horodov USSR. Kyiv. 1947 h. TsDAVO Ukrainy (Tsentr. derzh. arkhiv vyshch. orhaniv vlady ta upr. Ukrainy). F. 4906. Op. 2. Spr. 59. 197 ark.

[20] Uroven obrazovaniya, natsionalniy sostav, vozrastnaya struktura i razmeschenie naseleniya SSSR po respublikam, krayam i oblastyam po dannym Vsesoyuznoy perepisi naseleniya 1959 goda. Moscow: Gosstatizdat, 39.

[21] Ukrainska RSR. Administratyvno-terytorialnyi podil na 1 veresnia 1946 roku (1947). Kyiv: Ukrainske vydavnytstvo politychnoi literatury, 1063.

[22] Ukrainska RSR. Administratyvno-terytorialnyi podil na 1 sichnia 1972 r. (1973). Kyiv: Politvydav Ukrainy, 816.

[23] Ponomarenko, Yu. F. (Ed.) (1968). Istoriia mist i sil Ukrainskoi RSR. Luhanska oblast. Kyiv: Holov. red. URE AN URSR, 940.

[24] Analiz ta kompleksna otsinka mistobudivnykh umov ta perspektyv rozvytku merezhi mist URSR u zviazku z heneralnoiu skhemoiu rozmishchennia vyrobnychykh syl URSR na 1971-1980 rr. (druha cherha). 1969 r. TsDAVO Ukrainy Tsentr. derzh. arkhiv vyshchykh orhaniv vlady ta upr. Ukrainy F. 4906. Op. 6. Spr. 48.13 ark.

[25] Ukrainskaya SSR. Administrativno-territorialnoe delenie na 1 yanvarya 1979 goda (1979). Kyiv: Glavnaya redaktsiya Ukrainskoy Sovetskoy Entsiklopedii, 513.

[26] Ukrainska RSR. Administratyvno-terytorialnyi ustrii: na 1 sichnia 1987 roku (1987). Kyiv: Holov. Red. URE., 504.

Received date 26.04.2021

Accepted date 21.05.2021

Published date 31.05.2021
(C) The Author(s) 2021

This is an open access article under the Creative Commons CC BY license

How to cite. Bohunenko, V. (2021). Analysis of changes in the administrative-territorial status of monoprofile cities of Donbas (late 1940s - 1980s). EUREKA: Social and Humanities, 3, 58-64. doi: http://doi.org/10.21303/2504-5571.2021.001862 